\title{
Evaluation the pathogenecity of campylobacterjejuni hepatic toxin
}

Received :6 / 8 / 2018

Accepted : 29 / 8 /2018

\author{
AalaaFahim Abbas a , AzharImran Al-Thahab ${ }^{\text {b }}$

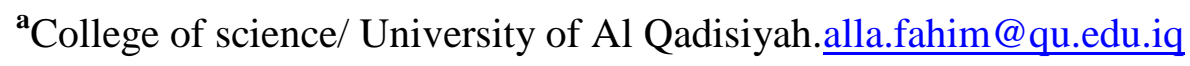 \\ ${ }^{\text {b College of Science / University of Babylon. azharammran@ yahoo.com }}$
}

\begin{abstract}
The current study investigated the gene responsible of hepatic toxin in Campylobacter jejuniisolatesthat isolated from children suffering diarrhea using polymerase chain reaction technique (PCR). The results showed that only one $C$. jejuni isolate that obtained from watery diarrheal stool was carrying hepatic toxin gene. Hepatic toxin was extracted fromproducedC.jejuniisolateand tested its effectiveness by liver function test in Swiss mice female type Balb/c (Mus musculus). The intravenous injection of $100 \mu \mathrm{g} / 0.5 \mathrm{ml}$ of hepatic toxin extract led to a significant increase in the mean concentration of liver enzymes Glutamate oxaloacetate transaminase (GOT) and Glutamate pyruvate transaminase (GPT), while the increase was not significant in mean concentration of the enzyme Alkaline phosphatase (ALP) compared with the control mice. In addition, histopathological study showed that hepatic toxinextracthad severe effects represented by multiple foci of inflammatory cells, bloody congestion, and necrosis in liver, hemorrhage and penetration of inflammatory cells in the spleen, while no histological changes was induced by hepatic toxin extract in the intestine.
\end{abstract}


KEYWORDS: Campylobacter jejuni, Pathogenicity, Hepatictoxin, Watery diarrhea, Bloody diarrhea, Hepatitis.

\section{INTRODUCTION}

C. jejuniisone of the main causes of gastroenteritis which transmitted through food and water, it occupies third place in developing countries as causative agent of diarrhea in children after EnterotoxigenicE. coli and Rotavirus, while more common than Salmonella and Shigella as causative agent of diarrhea in developed countries (1). The World Health Organization reported that diarrhea diseases and intestinal infections come in second place among the causes of deaths in children under five years of age, especially in developing countries (2), C. jejuni alone causes approximately 400 million cases of diarrhea per year (3).C. jejuni gastroenteritis is sometimes followed by unprecedented complications, ranging from localized peritonitis, pericarditis, hepatitis and encephalopathy to generalized neuropathy and bacteremia $(4,5)$.

C. jejuni has several mechanisms to cause gastroenteritis include colonization, invasion, translocation, and toxin production $(6,7)$. Motility was found necessary for the penetration of the intestinal mucosal barrier and colonization the mucous layer and reach the adhesion regions on intestinal epithelial cells and penetrate these cells. There by increasing the local concentration of toxic bacterial products $(8,9)$.

C. jejunihas been reported to produce four major groups of toxins, but their mechanism of action and their importance in disease remains unclear. There are: enterotoxin, cytotoxin, cytolethaldistending toxin and hemolysins(10). Among cellular toxins produced by $C$. jejuni, hepatotoxin. Kita et al., (11) found that some isolates of $C$.jejuni which were isolated from cases of watery diarrhea, bloody diarrhea, and other isolates from asymptomatic patients caused hepatitis when injected into the mice. It was found that these isolates produced a cellular hepatic toxin that toxic to mice liver cells line in vitro, but is not effective against Chinese hamster 
ovary $(\mathrm{CHO})$ or mouse adrenocortical (Y1) cell line, and injection of crude toxin or pure toxin in mice caused hepatic lesions similar to that lesions occurred after colonization of the liver by $C$. jejuni producing this toxin (12, 13).The present study was aimed to investigate hepatic toxin gene inC.jejuniisolatesby using PCR technique, and extraction of toxin from producing strain and test its effectiveness. Finally pathological study to the effect of the hepatic toxin in female Swiss mice, which include identifying Lethal Dose 50 (LD50) and histopathological study.

\section{MATERIALS\&METHODS}

\section{Molecular detection of hepatic} toxin:DNA was extracted,fromclinical eight isolates of C.jejuniwhichisolated from children suffering watery and bloody diarrhea, according to salting out method described by (14) and modified from (15). Bacterial extracted DNA was used as template in PCR technique to investigate the gene responsible for hepatic toxin. Primer sequencing as described by (16) has been used.

\section{Hepatic toxin extraction and} bioassay: Hepatic toxin was extracted according to (11). The effectiveness of the hepatic toxin extract was bioassayed in Swiss mice female type Balb / c mice (Mus musculus), through Liver function test.The mice were injected intravenously with $100 \mu \mathrm{g} /$ $0.5 \mathrm{ml}$ of hepatic toxin extract. The concentration of Glutamate oxaloacetate transaminase (GOT), Glutamate pyruvate transaminase (GPT), and Alkaline phosphatase (ALP)was assessed in mice sera at 2, 5 , and 10 days by Reflotronsystem.

\section{Histopathological study:LD50 for} hepatic toxin extract was determined according to (17). Histopathological changes in mice injected with $400 \mu \mathrm{g} /$ $0.5 \mathrm{~mL}$ of hepatic toxin extract was studied.

4. Statistical analysis: Analysis of variance in one direction (ANOVA one way) wasrelied to detect the differences between different groups and the level of probability $(\mathrm{P} \leq 0.005)$ was done through using statistical software (SPSS version 17).

\section{RESULTS\&DISCUSSION}

1. Molecular detection of hepatic toxin: Among eight isolates of $C$. jejuni isolated in the present study, 
only one isolate obtained from watery diarrhea was carrying the gene responsible of hepatic toxin with 530 base pair (bp) size as shown in Figure (1). Rizal et al.,(18) found that some C.jejunistrainsisolated from poultry and other strains isolated from humans diarrheawas carried gene responsible for cytotoxin stimulate hepatitis inflammation. Another study found that $15.7 \%$ of the C.jejunistrainsisolated from children suffering diarrhea carrying the gene responsible for inducing hepatitis (16).

\section{Hepatic toxin extraction and} bioassay:The current study showed that the intravenous injection of $100 \mu \mathrm{g}$ $/ 0.5 \mathrm{ml}$ of hepatic toxin extract led to a significant increase in meanconcentration of liver enzymes GOT and GPT in mice sera compared with those injected with C.jejunilipopolysaccharide(LPS) and control injected with phosphate buffer solution, while the increase was not significant in ALP enzyme concentration mean (table-1). The high concentration of liver enzymes due to the effect of the toxin on hepatic cell membrane and this effect leads to an increase in the permeability of the cell membrane and hepatic cell rupture (13).

\section{Histopathological study: LD50} dose was evaluated through intraperitoneal route in balb/c mice. The results of current study showed that the LD50 was about $866 \mu \mathrm{g} / \mathrm{ml}$. This result was lower than a result reported by Kita et al. (13) who found that LD50 of hepatic toxin extracted from C.jejunistrain isolated from watery diarrhea was $420 \mu \mathrm{g} / \mathrm{ml}$ while was $360 \mu \mathrm{g} / \mathrm{ml}$ for hepatic toxin extracted from C.jejunistrain isolated from bloody diarrhea. The difference in the LD50 values may be attributed to many factors included: the severity of the strain pathogenesis, extracted toxin purity, sensitivity of used lab animal, and time period used to preserve isolated bacterial strains.

The current study demonstrated that hepatic toxin extract hadn't induced any pathological changes in the intestine (Figure 2), while liver tissue sections showed signs of degeneration, hydropic degeneration, multiple foci of inflammatory cell infiltration as well as a severe necrosis, these changes did not notice in the control mouse liver (Figure 3,4). In 
spleen, hepatic toxin extract which lead to response to native or causedhemorrhage and penetration of inflammatory cells (Figure 5). The severity of pathological lesion in mice liver tissue such as necrosis, multiple foci of inflammatory cell infiltration emphasizes the role of this toxin as major stimuli of hepatitis (19). Some C.jejuni strains able to persist ingall bladder and liver for a long time after infection, these colonizing strainscontinue to produce hepatotoxic factor and stimulate hepatitis(12). Hepatic toxin act as hapten associated with components of hepatic cell membraneswhich are destroyed by the distorted hepatic cell, thus cause immunopathology. The persistent infiltration of mononuclear cells in liver tissue indicate a type of a hypersensitivity reaction and this shows that hepatitis resulting from immunological reactions (13).

\section{CONCLUSION}

Hepatic toxin is the main virulence factor that enable Campylobacter jejuni to induce hepatitis which supported by liver function test and histopathology lesions in experimental mice model.

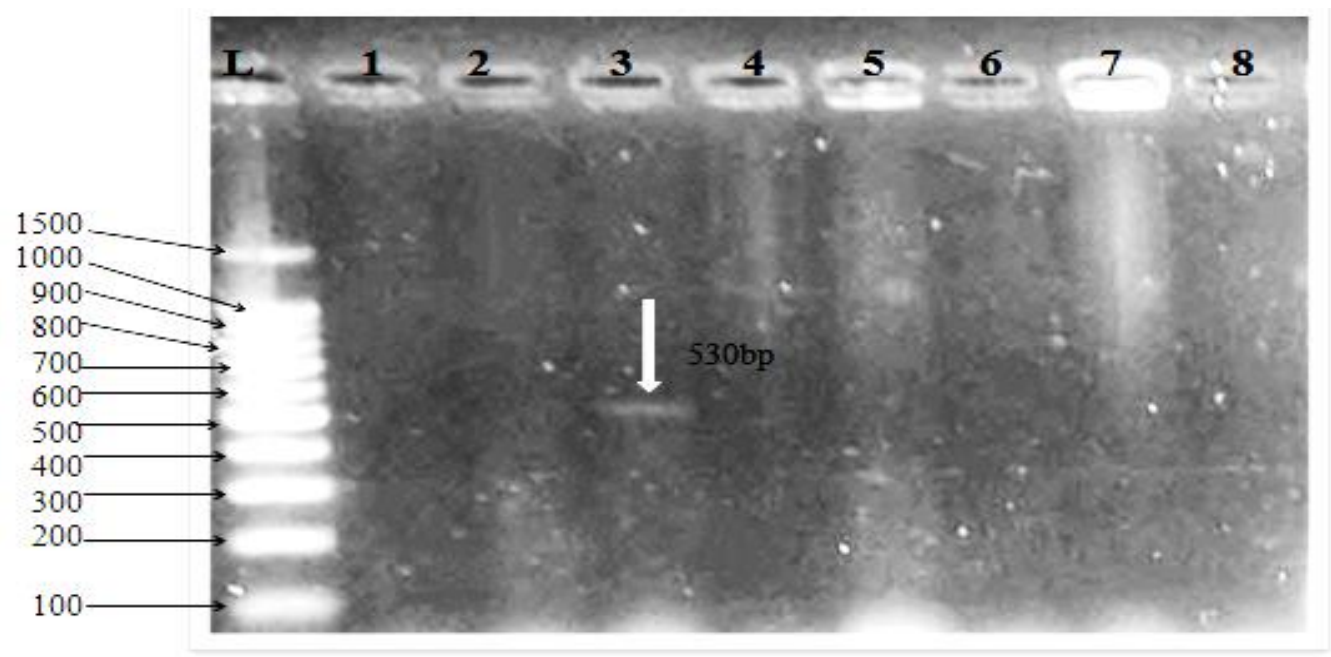

Figure(1): Agarose gel electrophoresis of PCR to hepatic toxin amplicon (530bp) for eight Campylobacter jejuni isolates. (L)represents DNA marker (100bp); Only isolate numbered (3) was positive, while isolates numbered $1,2,4,5,6,7,8$, were negative. 
Table (1): Mean concentration of liver enzymes (IU / ml)

\begin{tabular}{|c|c|c|c|c|}
\hline \multicolumn{2}{|l|}{ Liver enzymes con. } & $\mathbf{2}$ & $\mathbf{5}$ & 10 \\
\hline \hline \multirow{3}{*}{ Gays } & Hepatic toxin extract & $88.87 \pm 7.82$ & $120.32 \pm 4.6$ & $132.09 \pm 10.86$ \\
\cline { 2 - 5 } & LPS & $19.36 \pm 1.6$ & $22.48 \pm 2.26$ & $18.02 \pm 5.25$ \\
\cline { 2 - 5 } & Control & $59.53 \pm 1.34$ & $60.43 \pm 3.13$ & $59.23 \pm 2.15$ \\
\hline \hline \multirow{3}{*}{ GPT } & Hepatic toxin extract & $56.7 \pm 1.4$ & $77.1 \pm 2.47$ & $95.84 \pm 6.55$ \\
\cline { 2 - 5 } & LPS & $10.046 \pm 1.55$ & $19.53 \pm 1.53$ & $14.9 \pm 0.7$ \\
\cline { 2 - 5 } & Control & $27.9 \pm 2.6$ & $27.9 \pm 2.6$ & $27 . \pm 52.6$ \\
\hline \hline \multirow{3}{*}{ ALP } & Hepatic toxin extract & $75.56 \pm{ }^{*} 5.05$ & $85.13 \pm{ }^{*} 9.28$ & $99.57 \pm{ }^{*} 0.79$ \\
\cline { 2 - 5 } & LPS & $70 .{ }^{*} \pm 94.04$ & $80.78 \pm{ }^{*} 4.35$ & $92.59 \pm{ }^{*} 6.21$ \\
\cline { 2 - 5 } & Control & $69.4 \pm{ }^{*} 1.96$ & $69 . \pm 41.96$ & $69 . \pm 41.96$ \\
\hline
\end{tabular}

The numbers represent the mean of the three samples \pm standard deviation.

* Means the existence of differences are not significant.

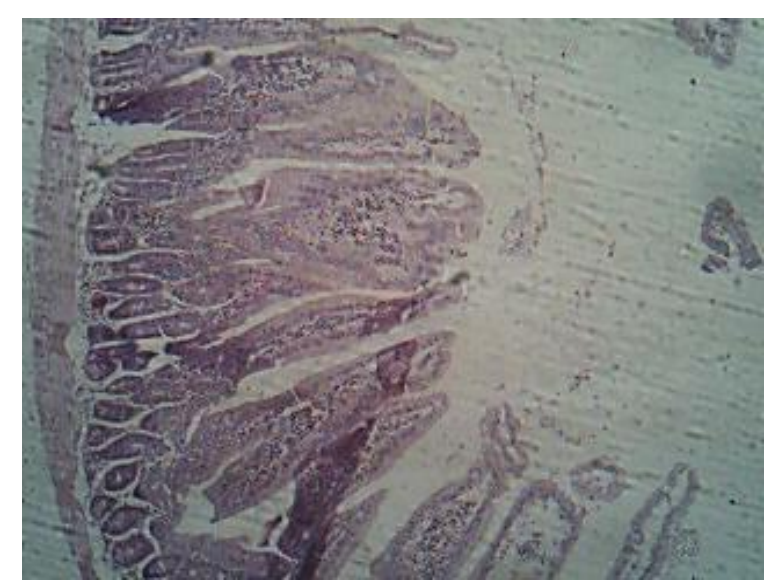

Figure(2): Cross-sectionin the mouse intestine injectedwith hepatic toxin, showsnormalintestinal villi(hematoxylin \& eosin (H \& E) 200X). 


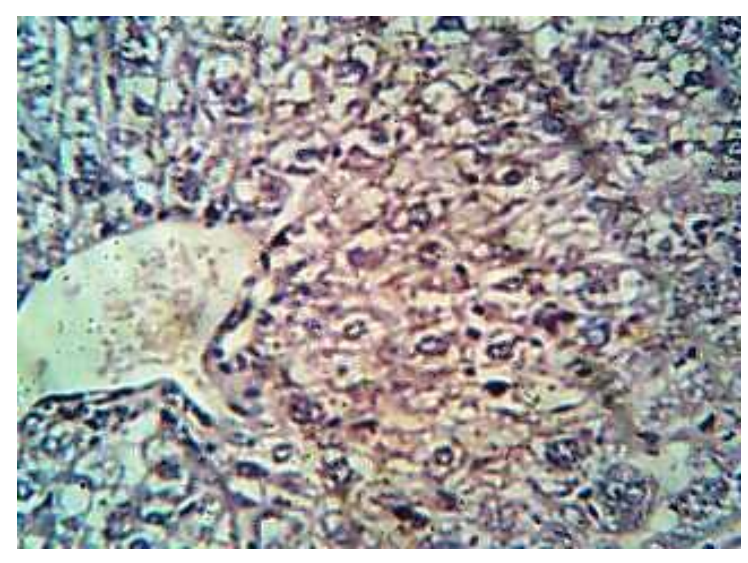

Figure (3): Cross-sectionin the mouse liver injectedwith hepatic toxin, explains:hydropic degeneration, necrosisalongthehepatictissue(H \& E.200X).

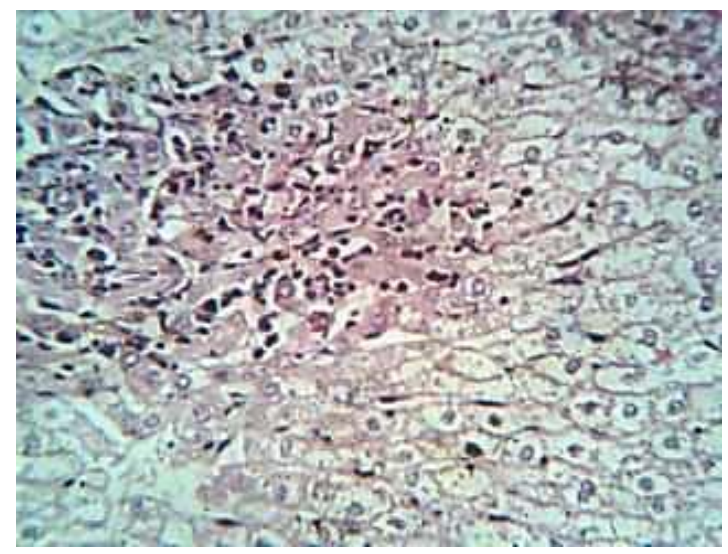

Figure (4): Cross-sectionin the mouse liver injectedwith hepatictoxin,explainsinflammatorycellsinfiltration(H \& E. 200X).

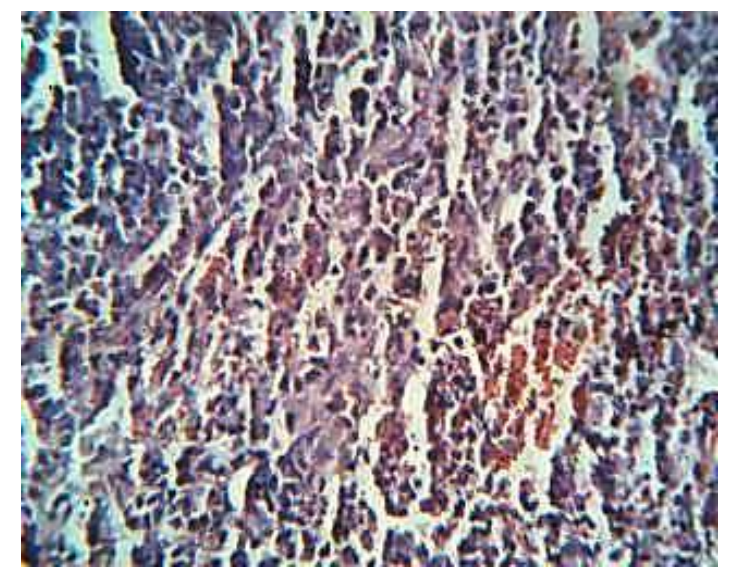


Figure(5): Cross-sectioninthemousespleeninjectedwith hepatic toxin explains: haemorrhageandpenetrationof inflammatory cells (H \& E. 200X).

\section{REFRENCES}

1- AL-Delaimi, M. S. and AL-Hadithi, R. (2008).Pathogenesisof Campylobacter jejuniinfection with emphasis on ultrastructural changes.Dohuk Med. J. 2 (1): 17-30.

2- Forsberg B. C.; Patzold M. G. and Cooke, M. (2007). Diarrhea case management in low and middle in some countries - an unfinished agenda. Bulletin of WHO, 85(1):265270.

3- Walker R. I. (2005). Considerations for development of whole cell bacterial vaccines to prevent diarrheal diseases in children in developing countries. Vaccine. 23:3369-85.

4- van Vliet, A.H.M. and Ketley J.M. (2001). Pathogenesis of enteric Campylobacter infection J. Appl. Microbiol. 90: 45-56.

5- Abruquah, H.H.(2009). Identificationof Host-pathogen Interacting Molecules ofCampylobacter jejuni using Phage Display Technology and in silico Sequence Analysis. Ph. D. thesis.School of Molecular Medical
Sciences. University ofNottingham. England.

6- Franco, D. A. (1988).Campylobacter species: considerations for controlling a foodborne pathogen. J. Food. Prot. 51: 145-153.

7- Konkel, M. E.; Montevile, M.; RiveraAmill, V. and Joens, L. A. (2001). The pathogenesis of Campylobacter jejunimediated enteritis. Curr. Issues Int. Microbiol. 2: 55-71.

8- Nuijten, P.J., van Asten, F.J., Gaastra, W., and van der Zeijst, B.A. (1990). Structural and functional analysis of two Campylobacterjejuniflagellin genes. J. Biol. Chem. 265: 1779817804.

9- Newat, C. and Jirog, S. (2009). PCR detection of four virulence-associated genes of Campylobacter jejuniisolates from thai broilers and their abilities of adhesion to and invasion of INT-407 cells. J. Vet. Med. Sci. 71(6): 839844.

10-Lee, A.; Smith, S.C. and Coloe, P.J. (2000). Detection of 
novalCampylobacter cytotoxin. J. Appl. Microbiol. 89: 719-725.

11-Kita， E.; Oku， D.; Hammuro, A.; Nishikawa, F.; Emoto, M.; Yagyu, Y.; Katsui, N. and Kashiba, S. (1990). Hepatotoxic activity of Campylobacter jejuni. J. Med. Microbiol. 33:171-183.

12-Kita, E.; Katsui, N. ; Emoto, M.; Yanagase, Y. and Kashiba, S. (1986). Hepatic lesions in experimental Campylobacter jejuniinfection of mice. J. Gen. Microbiol. 132:30953103.

13-Kita, E.; Nishikawa, F.; Kamikaidou, N.; Nakano, A.; Katsui, N. and Kashiba, S. (1992). Mononuclear cell response in the liver of mice infected with hepatotoxigenicCampylobacter jejuni. J. Med. Microbiol. 37:326-331. 14-Pospiech, T. and Neumann, J. (1995).In Genomic DNA isolation T. Kiesereds. John Innes Center. Norwich NR4 7UH.U.K.(Cited by Hadi, 2008).

15-Hadi， Z. J. (2008). Detection of extended-spectrum beta-lactamases of Escherichia coli and Klebsiellaspp. isolated from patients with significant bacteriuria in Najaf. M.Sc. Thesis. Medicine College. Kufa University.

16-Rozynek, E.; Dzierzanowska-Fangrat, D.; Jozwiak, P.; Popowski, J.; Korsak,
D. Dzierzanowska,
D. (2005).

Prevalence of potential virulence markers in Polish Campylobacter jejuniand Campylobacter coli isolates obtained from hospitalized children and from chicken carcasses. J. Med. Microbiol. 54:615-619.

17-Reed, J. and Muench, H. (1938). A simple method of estimating fifty percent end points. Am.J. Hyg. 27: 493-497.

18-Rizal, A.; Kumar, A. and Vidyarthi, A.S. (2010). Prevalence of pathogenic genes in Campylobacter jejuniisolated from poultry and human. J. Food Safety. 12: 29-34.

19- AL-Juboori, A. N. K. (2010). Pathogenesis of Campylobacter jejunienteritis histopathological and electron microscopy changes. XXVI world buiatrics congress, Santigo, Chile, 521:94-101. 